\title{
The Effect of Negative Publicity on Brand Equity (Image Attitude, and Purchase Intention) in Indonesia: Case of Dolce and Gabbana Racism Scandal
}

\author{
Mawaddah Ilona Maslikhan * \\ University of Hull, Hull, United Kingdom \\ School of Business and Management, \\ Bandung Institute of Technology, Bandung, Indonesia
}

\begin{abstract}
The paper examines the effect of negative publicity on brand attitude, brand image, and purchase intention in the context of Luxury Brand in Indonesia by seeing the influence of negative publicity has on both brand attitude, and brand image, which later on correlated with purchase intention to see the relationship purchase intention has on brand attitude and brand image. The study uses a quantitative approach through an online questionnaire in which 104 responses were gathered using a convenience sampling approach and analyzed using Wilcoxon Signed Rank Test and Spearman Correlation test. The result of the analysis shows that negative publicity has negative influence on brand attitude and brand image. The findings also shown the strong positive relationship is existed between brand attitude \& purchase intention, and brand image \& purchase intention. On the other hand, the correlation also existed between racism awareness and concern, and purchase intention after negative publicity exposure, only that it is very weak. The result may be caused by the negative information given is not about racism in Indonesia itself, but in China, so even the tendencies of Indonesian in racism awareness and concern is high, it will not necessarily result in the same degree as the purchase intention. Hopefully, this research will be useful and give the proper managerial implication for luxury brand companies when they encounter such negative publicity, emphasizing cultural and racism issues.
\end{abstract}

Keywords: Negative publicity, brand attitude, brand image, purchase intention, racism awareness and concern

Received: 22 April 2019; Accepted: 26 May 2019; Published: 21 June 2019

\section{INTRODUCTION}

\section{Statement of the Problem}

Dealing with negative publicity is truly important in marketing because it appears that there is a direct impact between negative publicity of companies and the product's sales, consumer's attitude towards the brand as well (Cho, 2005). Previous studies also indicated that negative brand information would negatively influence the brand attitudes and/or purchase intention (Ahluwalia \& Gürhan-Canli, 2000; Ullrich \& Brunner, 2015). Especially emerging social media, that have the power to escalate something that is trending, can make video advertising of a product viral easily and increase its sales, but in the other hand their power can work otherwise as well. Today younger generation tends to be more sensitive and vocal regarding social and environmental issues which reflects on their shopping behavior that prefers companies and brands reflecting their value. The possibilities are higher for companies and brands to face

*Correspondence concerning this article should be addressed to Mawaddah Ilona Maslikhan, University of Hull, United Kingdom E-mail: mawaddahilonamaslikhan@gmail.com

(c) 2019 The Author(s). Published by KKG Publications. This is an Open Access article distributed under a Creative Commons Attribution-NonCommercial-NoDerivatives 4.0 International License. 
backlash and financial consequences when the issue of racism, tokenism, cultural appropriation, and misrepresentation arises, especially in fashion and beauty industries (Fernandez, 2019). The upsurge of "call-out" culture means that publicity crises will more likely be encountered by fashion and beauty brands, which can change a few tweets or posts into worldwide news just in hours (Fernandez, 2019).

Following the issue, Dolce and Gabbana $(D \& G)$ recently encountered a major negative publication. D\&G, an Italian Luxury Fashion Brand, has just canceled a high-profile catwalk show in Shanghai following an amid racist accusation perceived by many Chinese over its latest ad campaign (Yang \& Liu, 2018). The campaign showed a video of a Chinese model attempting to eat Italian food using chopstick which later on was taken down from Weibo less than 24 hours, but already widely spread on Instagram and Chinese social media platforms. The blunder was heightening when Diet Prada exposed a private Instagram message (in what D\&G claimed as a result of hack) where Stefano Gabbana told that "China is a shitty country" and "ignorant, dirty, and smelly mafia" (Cristoferi, 2019).

Influential Chinese celebrities, models, and customers boycott the brand, China's largest e-commerce giants like Secco and Tmall as well as global luxury e-commerce leader Yoox Net-a-Porter also joined the boycott by removing Dolce \& Gabbana products online (Yang \& Liu, 2018). Such negative publicity is devastating for the company, causing a tremendous revenue loss and market share. It also negatively affects how company and its brand are perceived by consumers (Cho, 2005). Therefore, Khorami (1991) said that negative information is essential for customer's buying behavior as it is damaging advertisers' brand image. Brand image itself has perceptual and subjective traits which are formed by emotional or rational customer's interpretation (Cho, 2005). Because of its traits, brand image is vulnerable to negative brand information. And when brand image encountered by negative information, it will more likely result in less preference and purchase intention (Cho, 2005; Wichailert \& Yousapornpaiboon, 2017). Chelminski and Coulter (2011) suggested that brand image is more abiding compared to attitude; thus, it may be less affected by negative information compared to other factors, such as brand attitude (Park, MacInnis, Priester, Eisingerich, \& Iacobucci, 2010). Yu, Liu, Lee, and Soutar (2018) stated that there is no prior research comparing the effect of negative publicity on brand attitude and brand image.

Moreover, most negative publicity researches are focused on Western customers where only small emphasized on consumers from other culture. Yu et al. (2018) thought that it might be important because it is proven that cultural disparity affects customers' reaction towards negative publicity. Lastly, the study of negative publicity emphasizing on the racism issue is not yet to be found. Therefore the writer will make an assumption about how the level of concern and awareness towards racism have any correlation with purchase intention after the negative publicity exposure, adopting from Grimmer and Bingham (2013) study about level of involvement towards eco cautiousness. The context of the study will be negative publicity on a luxury fashion brand, and the writer chose Indonesia as the subject of study because of its growing luxury market that expected to increase annually.

\section{Objectives}

1) To identify the influence of negative publicity have on Dolce \& Gabbana's brand attitude and brand image.

2) To identify the relationship between brand attitude and brand image towards consumers purchase intention before and after negative publicity exposure.

3) To identify the relationship between the level of concern and awareness on the racism issue in fashion industry towards consumers purchase intention after negative publicity exposure.

\section{Rationale of the Study}

Previous researches have conducted research about the impact of negative publicity on brand attitude, brand image, and purchase intention. Most of them are not specifying the sector of the industry in the analysis, only a few specifying on certain industry for example like what Dimitrova (n.d.) has done in the green brand advertising. The author found that there is a gap between negative publicity research on the author's subject interest which is luxury brand. The study on the existence of relationship between racism awareness and concern and the previous subject matter in brand equity will be the uniqueness of the study. 
Hopefully, this research will be useful and could give the proper managerial implication for luxury brand companies when they encounter such negative publicity, which emphasizes the understanding of cultural and racism issue.

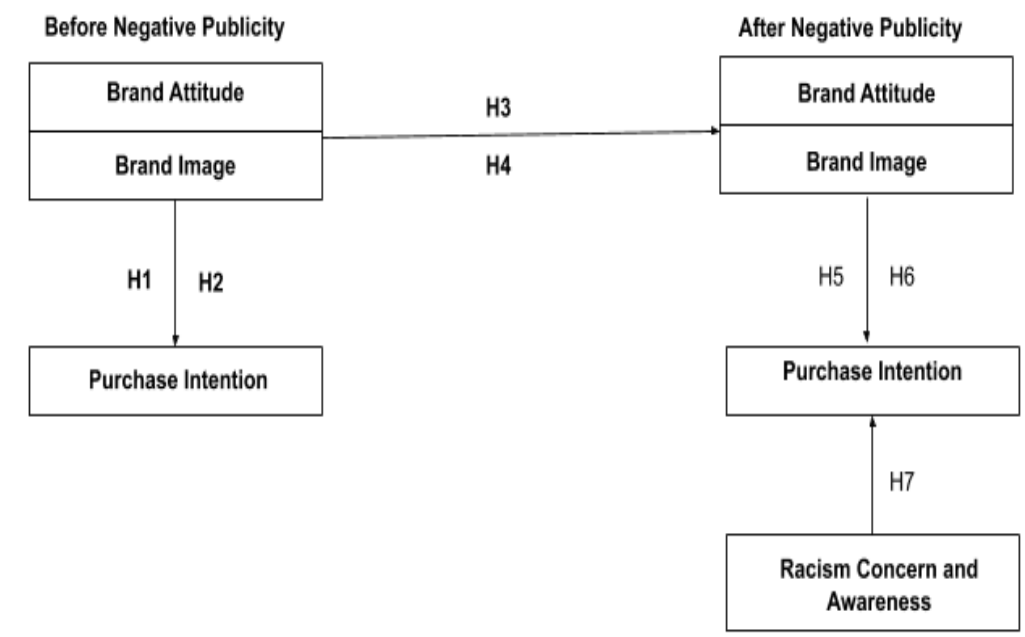

Figure 1 Conceptual Framework of the Study

\section{LITERATURE REVIEW}

\section{Negative Publicity and Advertising}

Various form of persuasive communication such as publicity, advertising, or the third-party endorsement can cause either positive or negative information about a brand and company (Cho, 2005; Ramly \& Omar, 2016). Bond and Kirshenbaum (1998) believed that publicity tends to be more credible and influential compared to company-controlled communication. In today's emerging market, negative publicity about products and companies are easily widespread (Claeys \& Cauberghe, 2014), and can be described as a potentially harmful information about product, business unit, person, or service, which circulated through broadcast media, WOM, or print (Sherrell, Reidenbach, Moore, Wagle, \& Spratlin, 1985). Not only the company but also stakeholder will as well be harmed when negative publicity concerning brand is confirmed and made official (Claeys \& Cauberghe, 2014) through, for instance, attitude changes (Dahlen \& Lange, 2006). When it comes to attribution of product beliefs, negative information is known to be more powerful compared to positive information (Dahlen \& Lange, 2006). Negative brand information has a bigger impact on decision making compared to positive or neutral brand information, and it results to be an impression towards companies (Cho, 2005). However, even though the crises happen at the same time or within the same category of product, the length in which negative publicity will be known by public can be differ a lot between certain brands (Cleeren, Van Heerde, \& Dekimpe, 2013), such as Dolce \& Gabbana racism issue which is more affected by the negative publicity rather than Gucci and Prada's racism issue (Fernandez, 2019).

\section{Brand Attitude}

As an important component of brand equity, brand attitude indicates a consumer's evaluation and feelings of a brand's product or service (Aaker, 2009; Hajdas, 2017; Keller, 1993). Brand attitude defined as the positive and negative views of individuals towards objects, people, occasions, or behaviors projecting the preferences towards those objects, people, occasions, or behaviors, which develops positive or negative intention towards purchase behavior (Park et al., 2010). Brand attitude can last for a long time and could be changed when customers encounter new experience or reflections (Solomon, 2008). It has been widely considered in numerous field that brand attitude has a positive relationship with purchase intention (Fishbein \& Ajzen, 1977; Sierra \& Hyman, 2011). Brand attitude has often been applied in the construction of negative brand information research (Ullrich \& Brunner, 2015), and the most previous studies shown that negative brand information has a direct, powerful, and negative impact on consumer's overall attitudes towards the affected brand (Ahluwalia \& Gürhan-Canli, 2000). 


\section{Brand Image}

Brand image is another important component of brand equity which can be defined as how the consumers perceive on specific brand attributes (i.e., whether the brand is fashionable, stylish, or innovative) (Keller, 1993; Magnusson, Krishnan, Westjohn, \& Zdravkovic, 2014). Particularly, brand image is what customers' overall subjective perception have towards a brand, and how it differs from other brands because of its uniqueness (Faircloth, 2005). In corporate marketing, brand image holds an essential role in which customers see it as sort of knowledge that other than affecting the overall image of a company, it also have has fundamental role in purchase intention (Chao, Liao, et al., 2016). Previous studies have found that negative brand information destroys brand image (DeCarlo, Laczniak, Motley, \& Ramaswami, 2007; Raju, Unnava, \& Montgomery, 2009). Purchase intention is likely to be influenced by the harm to brand image (Wu, 2011).

\section{Purchase Intention}

Purchase intention is defined as a form of decision-making which analyzes the consumers' intention to buy certain brand. Purchase intention is said to be an efficient tool for predicting buying process, additionally it can assess the consumers' likelihood to purchase certain product, the higher the purchase intention, the higher consumers eagerness to purchase that product (Schiffman \& Kanuk, 2000). Previous researches have found that there is significant relationship between brand image and consumers' purchase intention (Tariq, Nawaz, Nawaz, \& Butt, 2013). Study The study conducted by Hernández and Küster (2012) also proposed that brand attitude has significantly influenced consumers' purchase intention.

\section{Racism Issue Awareness and Concern in Fashion Industry}

During this era of emerging internet, particularly social media giving a free voice to experts and amateurs alike, accusations of racism have been heating up for quite a while. From all-white catwalks, cultural symbol being ripped off and inappropriately sold to the market, to an offensive cultural stereotype advertising, we are more aware than ever how our self-righteous behavior can make such offense and excludes others. In the UK, a recent discussion on the racism matter came into The Fashion Debates, where fashion industry professionals coming together and discuss the crucial issues around the ethics of racism matter. Referring to Euclid Analysis in 2017, consumers are no longer willing to connect with brand, which presents bad behavior and poor judgement. From the Euclid "What Kills Customer Loyalty Survey" report surveying American consumers, shows that $58 \%$ of the respondents will undoubtedly boycott the brands or companies which appeared to be racist and 50\% would boycott for those who appeared sexist.

While it is not the most popular issue currently in Indonesia, the author would like to know whether or not the level of racism concern and awareness in Indonesia has any relationship towards consumers' purchase intention after the negative publicity exposure.

\section{Research Hypotheses}

H1: Brand attitude positively correlated with purchase intention.

H2: Brand image positively correlated with purchase intention.

H3: Negative information about $D \& G$ negatively influences brand attitude.

H4: Negative information about $D \& G$ negatively influences brand image.

H5: Brand attitude positively correlated with purchase intention after negative publicity exposure.

H6: Brand attitude positively correlated with purchase intention after negative publicity exposure.

H7: The level of awareness and concern correlated with purchase intention after negative publicity exposure.

\section{RESEARCH METHODOLOGY}

\section{Population and Sample Size}

The population, from which the sample of the current research was drawn, was Indonesian. Sample indicates to small group of "cases" which become a representation of a larger population (Henry, 1990). As it is impossible to do an observation of the whole Indonesian population because of its size, sample is used in conducting this research. Due to the limited time and resources, the author use sampling frame of convenience sample, a type of non-probability 
sampling (Lekvall \& Wahlbin, 2001; Bryman \& Bell, 2011). Sampling frame of this research is as follows:

- For ethical reason, the minimum limit of the respondent age is 18.

- Respondent is an Indonesian who knows about the brand Dolce \& Gabbana. It is important as the questionnaires' questions revolved around the brand attitude, images, and purchase intention about Dolce \& Gabbana.

To make sure that the intended respondents meet the requirements, the age limit is purposely start from range 18-24 and if the respondents responded "No" to the question "Do you know the brand Dolce \& Gabbana and its products?", it directly submitted and finished the questionnaire.

\section{Quantitative Research}

Primary data is the original data source which collected or observed first-hand by the researcher for specific purpose or project. A questionnaire is distributed as the most widely used method in primary data (Diamantopoulos \& Schlegelmilch, 1996). It is also used because the questionnaires can be completed by the respondents' convenience, and enabling the researcher to gather important information using diverse question types (Evans \& Mathur, 2005; Bryman \& Bell, 2011). Due to geographical condition and time limitation, questionnaires were distributed through an online survey using Google Forms, consists of 39 questions, 1 video, 1 picture, and 2 short news from credible source (Independent and Daily Mail UK). The respondents have to be an Indonesian, age 18 or more, and know about the brand Dolce \& Gabbana and its products. The questionnaires were distributed through social media and only messaging, in a week from March 28th to April 4th. Respondents are instructed to read the instruction carefully prior to answering the questions which already programmed as required answers so that no questions will be left blank.

The questionnaires started with four demographic questions concerning the respondents' age, gender, occupation, and city of residence. Followed by closed-ended questions about brand familiarity, luxury product involvement, frequency of purchase, and luxury product selection to help the author answer the first research question. Lastly, the main parts of the questions about brand attitude, brand image, and racism concern and awareness are asked using close-ended questions which structured using 5-point Likert type scale. The questionnaire can be seen in appendix 5 . The questionnaires were opened for answers within a week, and the total amount of respondents gathered was 124. The analysis will be done by SPSS non-parametric statistic using median measurement Wilcoxon signed-rank test and Spearman's rank-order correlation. After that, the result from the descriptive statistic tools and hypothesis testing will be interpreted based on the concept theory to answer each research questions.

\section{Reliability Test}

Oppenheim (1992) stated that reliability indicated to repeatability, for example, the questionnaire can prove the consistency findings whenever employed. Cronbach's Alpha is the most common method to measure internal consistency by using inter-item correlations. According to (Bryman \& Bell, 2011), all Cronbach's Alpha coefficient exceeding the acceptable level of 0.7 , signifies that the research is reliable.

Table 1 RELIABILITY TEST RESULTS

\begin{tabular}{lll} 
Variable & Cronbach's Alpha & Criteria \\
\hline Brand Attitude Before (BAB) & & Reliable \\
Brand Image Before (BIB) & 0.902 & Reliable \\
Purchase Intention (PIB) & 0.926 & Reliable \\
Brand Attitude After (BAA) & 0.891 & Reliable \\
Brand Image After (BIA) & 0.948 & Reliable \\
Purchase Intention After (PIA) & 0.949 & Reliable \\
Racism Concern \& Awareness (RCA) & 0.937 & Reliable \\
\hline
\end{tabular}

From the Table 1 we can see that the cronbach's alpha exceeding 0.7 , ranging from $0.814-0.955$. It indicates that the study was reliable. 


\section{RESULTS}

Table 2 SPEARMAN CORRELATION TEST

\begin{tabular}{llll}
\hline Spearman's rho Correlation & Coefficient & Sig. (2-tailed) & $N$ \\
\hline BAB - PIB & & & \\
BIB - PIB & .580 & .000 & 104 \\
BAA - PIA & .512 & .000 & 104 \\
BIA - PIA & .724 & .000 & 104 \\
RAC - PIA & .724 & .000 & 104 \\
\hline
\end{tabular}

$\mathrm{H} 1$ : we can see that there is a significant correlation between brand attitude and purchase intention before the negative publicity exposure (BAB - PIB) (Sig. (2-tailed) $0.000<0.05$ ). The correlation coefficient is 0.580 . As the sign of spearman's correlation is positive, we can conclude that there is a positive correlation between brand attitude and purchase intention before and after the negative publicity exposure. The coefficient score of 0.580 also suggests that variable $\mathrm{BAB}$ and $\mathrm{PIB}$ have a strong positive correlation. Therefore, we can accept $\mathrm{H} 1$.

$\mathrm{H} 2$ : we can see that there is a significant correlation between brand attitude and purchase intention before the negative publicity exposure (BIB - PIB) (Sig. (2-tailed) $0.000<0.05$ ). The correlation coefficient is 0.512 . As the sign of spearman's correlation is positive, we can conclude that there is a positive correlation between brand attitude and purchase intention before and after the negative publicity exposure. The coefficient score of 0.512 also suggests that variable BIB and PIB have a strong positive correlation. Therefore, we can accept $\mathrm{H} 2$.

H3: Out of 104 respondents, the negative information of $D \& G$, causing a decline in brand attitude in all of the respondents. Negative information about D\&G caused a statistically significant median decrease in brand attitude, $\mathrm{z}=-8.864$, Sig. (2-tailed) $0.000<0.05$. Therefore, we can accept H3 because negative information about Dolce \& Gabbana negatively influences brand attitude.

$\mathrm{H} 4$ : Out of 104 respondents, the negative information of $\mathrm{D} \& \mathrm{G}$, causing a decline in brand image in 77 of the respondents, whereas 27 respondents show no change in brand image. Negative information about D\&G caused a statistically significant median decrease in brand image, $z=-7.661$, Sig. (2-tailed) $0.000<0.05$. All in all we can accept $\mathrm{H} 4$ because even that there is 27 ties rank, the negative ranks are significantly higher, so negative information about Dolce \& Gabbana negatively influences brand attitude.

H5: we can see that there is a significant correlation between brand attitude and purchase intention after the negative publicity exposure (BAA - PIA) (Sig. (2-tailed) $0.000<0.05$ ). The correlation coefficient is 0.724 . As the sign of spearman's correlation is positive, we can conclude that there is a positive correlation between brand attitude and purchase intention before and after the negative publicity exposure. The coefficient score of 0.724 also suggests that variable BAA and PIA have a strong positive correlation. Therefore, we can accept H5.

H6: we can see that there is a significant correlation between brand attitude and purchase intention after the negative publicity exposure (BIA - PIA) (Sig. (2-tailed) $0.000<0.05$ ). The correlation coefficient is 0.724 . As the sign of spearman's correlation is positive, we can conclude that there is a positive correlation between brand attitude and purchase intention before and after the negative publicity exposure. The coefficient score of 0.724 also suggests that variable BIA and PIA have a strong positive correlation. Therefore, we can accept H6.

$\mathrm{H} 7$ : We can see that there is a significant correlation between brand attitude and purchase intention before the negative publicity exposure (RAC - PIA) (Sig. (2-tailed) $0.046<0.05$ ). The correlation coefficient is -.215. As the sign of spearman's correlation is negative, we can conclude that there is a negative correlation between brand attitude and purchase intention before and after the negative publicity exposure. The coefficient score is -.215; it means that the correlation between variable RAC and PIA is a negative, very weak correlation. However we can still accept $\mathrm{H} 7$ because the correlation exists but very weak. 


\section{RESULTS}

Table 3 WILCOXON SIGNED RANK TEST

\begin{tabular}{|c|c|c|c|c|c|c|}
\hline & & $N$ & Mean Rank & Sum of Rank & \multicolumn{2}{|l|}{ TestStatistics ${ }^{g}$} \\
\hline \multirow[t]{3}{*}{ BAA - BAB } & Negative Ranks & $104^{a}$ & 52.50 & 5460.00 & \multirow{2}{*}{$\mathrm{Z}$} & \multirow[t]{2}{*}{$-8.864^{h}$} \\
\hline & Positive Ranks & $0^{b}$ & .00 & .00 & & \\
\hline & Ties & $0^{c}$ & & & Asymp. Sig. (2-tailed) & .000 \\
\hline \multirow{4}{*}{ BIA - BIB } & Negative Ranks & $\begin{array}{l}104 \\
77 d d\end{array}$ & 3900 & 300300 & \multirow[b]{2}{*}{$\mathrm{Z}$} & \multirow[b]{2}{*}{$-7.661^{h}$} \\
\hline & Positive Ranks & $0^{e}$ & .00 & .00 & & \\
\hline & Ties & $27^{f}$ & & & \multirow{2}{*}{ Asymp. Sig. (2-tailed) } & \multirow{2}{*}{.000} \\
\hline & Total & 104 & & & & \\
\hline
\end{tabular}

\section{CONCLUSION AND MANAGERIAL IMPLICATIONS}

\section{Conclusion}

The key trends shaping the growth and importance of luxury markets in Indonesia is showing solid annual advancing growth rates that were achieved by new competitive International Marketing and Business Strategies as to provided fresh and niched product experience catering for the new competitive landscape. As Indonesia becoming one of the top destinations of luxury brands in the South-East-Asia region, it is important for marketers to pay special attention to and be careful in maintaining its good publicity, especially on the sensitive issues of cultural and racial matters. Because the ramifications of negative publicity to a luxury brand company will negatively impact its brands and will consume significant amount of times and resources to do the "damage control" of the issue. Therefore, in this research, several findings have been examined and concluded to help companies especially luxury brands companies, to have an in-depth-understanding about negative publicity and racism, as well as to heighten its awareness and concern of the subject. Having eclectic understanding of these complex yet important cultural issues will help the brands and company to generate the coveted sustainable business growths while maintaining good brand equity.

From the results, we can conclude that the negative information about brand D\&G has negative influences towards both brand attitude and brand image. Moreover, brand attitude has strong positive relationship with purchase intention, as well as brand image which also has a strong positive relationship with purchase intention, before and after the negative publicity is exposed. However, the degree of relationship between brand attitude - purchase intention, and brand image - purchase intention is getting stronger after being exposed by negative publicity. An additional variable is added to understand the relationship between purchase intention and, racism awareness and concern. The result shows that there is a significant negative relationship between these two variables. However, the strength of the relationship is very weak, which may be caused by the information presented was not about Indonesian culture; hence, it is less sensitive to the purchase intention behavior. However, in the future companies need to put more emphasized on racism issue and hire local expert to understand the do's and dont's regarding advertising or another form of marketing when venturing to a new competitive landscape where traditional corporate strategies that the Company is used to incorporate are no longer relevant.

\section{LIMITATION AND SUGGESTION FOR FUTURE RESEARCH}

There are several limitations in this research that are important to emphasize. Firstly, the sample included in the surveys is mostly university students age 18-24. Therefore, their responses to negative publicity may not be the same as other groups like older age group who already works and have higher bargaining purchase on luxury brand which may be more well-suited for this kind of research. However, young consumers are key for most product categories specifically luxury brand due to their customer lifetime value. Therefore, it is important for marketers to understand how such customers respond to negative publicity.

Secondly, the implementation of using questionnaires and Likert-scale as methods of data collection creates a close-ended answer, in which the author needs to interpret Indonesian perspective when choosing the answers related to 
the research topic. In addition, a close-ended can be a challenge to analyze the reasons behind consumer behavior in Indonesia regarding the negative publicity issue in racism merely by number (ordinal data). It may be better for future research to use mixed-method, where the qualitative method could gather more explanatory information, opinion, and arguments about the matters. Moreover, Regarding the variable of racism awareness and concern, it is suggested to use this as a third moderating variable rather than a direct dependent variable on purchase intention, to measure the strength of the relationship between a dependent and independent variable in correlation, assuming the data is parametric.

Thirdly, the questionnaire contains 39 closed-ended questions, 1 video, 1 picture, and 2 short news, apparently causing various spending time in doing the questionnaire, signifies some of the respondents carefully and wisely answering the questionnaires, while some others were skimming the questionnaires. Moreover, it is also important to address that this research had a limited sample which presumably causing the data violates some assumption to be analyzed using parametric test, which considerably has more power compared to non-parametric test, and hence can examine the influence between independent and dependent variable (i.e. multiple regression), though bear in mind, it is not always the case. For future research, larger sample size is necessary to generate more reliable results and further create more generalizable results. Because of the limited resource and time the author had, the questionnaire was distributed through social media and online messaging to family and friend which is not optimal and tend to generate bias result. Therefore, it is suggested for future research to use a larger random sample to ensure realistic results.

\section{MANAGERIAL IMPLICATIONS}

The research mainly looks at how the negative publicity influence the brand attitude and brand image, which leads to the purchase intention of consumers. The subject of the study is emphasizing on luxury brands with additional consideration on racism awareness and concern.

The findings can thus provide recommendations for public relation specialists, brand managers, marketing practitioners, specifically those in the luxury industry, to establish, develop, and maintain favourable and strong brand. Scandals like Dolce \& Gabbana prove that fashion and luxury companies cannot neglect stakeholder expectation for conversation, transparency, openness, and accountability. One factor that luxury brands often underestimate is the symbolic relationship which they have with the consumers. Langer (2019) recommended doing a conditional analysis, applying digital and managerial procedures which guide the global company to think and perform locally and put the focus on reconstructing brand equity.

Negatively publicity definitely harms the brand equity of the brand, especially with current rapid information flow and the emerging social media. Companies need to put more emphasis on following the news online to keep up to date on certain issue(s). Diversity is also needed in the management of a company to have more understanding of specific cultural dimension in certain country so that what happened on Dolce \& Gabbana can be avoided.

\section{REFERENCES}

Aaker, D. A. (2009). Managing brand equity. New York, NY: Simon and Schuster.

Ahluwalia, R., \& Gürhan-Canli, Z. (2000). The effects of extensions on the family brand name: An accessibilitydiagnosticity perspective. Journal of Consumer Research, 27(3), 371-381. doi:https://doi.org/10.1086/317591

Bond, J., \& Kirshenbaum, R. (1998). Under the radar: Talking to today's cynical consumer (Vol. 2). New Jersey, NJ: John Wiley \& Sons.

Bryman, A., \& Bell, E. (2011). Ethics in business research. Business Research Methods, 7(5), 23-56.

Chao, R.-F., Liao, P.-C., et al. (2016). The impact of brand image and discounted price on purchase intention in outlet mall: Consumer attitude as mediator. The Journal of Global Business Management, 12(2), 119-128.

Chelminski, P., \& Coulter, R. A. (2011). An examination of consumer advocacy and complaining behavior in the context of service failure. Journal of Services Marketing, 25(5), 361-370. doi:https://doi.org/10.1108/ 08876041111149711

Cho, Y. Y. (2005). The effect of negative publicity on consumers' brand evaluation: The moderating role of corporate advertising (Unpublished master's thesis). Columbia, US: University of Missouri.

Claeys, A.-S., \& Cauberghe, V. (2014). What makes crisis response strategies work? The impact of crisis involvement and message framing. Journal of Business Research, 67(2), 182-189. doi:https://doi.org/10.1016/j.jbusres.2012 .10 .005 
Cleeren, K., Van Heerde, H. J., \& Dekimpe, M. G. (2013). Rising from the ashes: How brands and categories can overcome product-harm crises. Journal of Marketing, 77(2), 58-77. doi:https://doi.org/10.1509/jm.10.0414

Cristoferi, C. (2019, August). Dolce \& Gabbana sees sales slowdown in China after ad backlash. Reuters. Retrieved from https://reut.rs/2k44rhh

Dahlen, M., \& Lange, F. (2006). A disaster is contagious: How a brand in crisis affects other brands. Journal of Advertising Research, 46(4), 388-397. doi:10.2501/S0021849906060417

DeCarlo, T. E., Laczniak, R. N., Motley, C. M., \& Ramaswami, S. (2007). Influence of image and familiarity on consumer response to negative word-of-mouth communication about retail entities. Journal of Marketing Theory and Practice, 15(1), 41-51. doi:https://doi.org/10.2753/MTP1069-6679150103

Diamantopoulos, A., \& Schlegelmilch, B. B. (1996). Determinants of industrial mail survey response: A surveyon-surveys analysis of researchers' and managers' views. Journal of Marketing Management, 12(6), 505-531. doi:https://doi.org/10.1080/0267257X.1996.9964432

Dimitrova, B. (n.d.). Green brand positioning: Emotional versus functional brand positioning and the influence of negative publicity (Unpublished master's thesis). Rotterdam, Netherlands: Erasmus School of Economics.

Evans, J. R., \& Mathur, A. (2005). The value of online surveys. Internet Research, 15(2), 195-219. doi:https://doi.org/ $10.1108 / 10662240510590360$

Faircloth, J. B. (2005). Factors influencing nonprofit resource provider support decisions: Applying the brand equity concept to nonprofits. Journal of Marketing Theory and Practice, 13(3), 1-15. doi:https://doi.org/10.1080/ 10696679.2005 .11658546

Fernandez, C. (2019, January). American vogue apologises for misidentifying Muslim American journalist. Retrieved from https://bit.ly/2lzPc01

Fishbein, M., \& Ajzen, I. (1977). Belief, attitude, intention, and behavior: An introduction to theory and research. Boston, MA: Addison-Wesley.

Grimmer, M., \& Bingham, T. (2013). Company environmental performance and consumer purchase intentions. Journal of Business Research, 66(10), 1945-1953. doi:https://doi.org/10.1016/j.jbusres.2013.02.017

Hajdas, M. (2017). The impact of cultural branding on brand equity-exploratory study. Handel Wewnetrzny, 5(3), 213-221.

Henry, G. (1990). Practical sampling. Newbury Park, CA: Sage Publications, Inc.

Hernández, A., \& Küster, I. (2012). Brand impact on purchasing intention. an approach in virtual social networks channels. Economics and Business Letters, 1(2), 1-9.

Keller, K. L. (1993). Conceptualizing, measuring, and managing customer-based brand equity. Journal of Marketing, 57(1), 1-22. doi:https://doi.org/10.1177/002224299305700101

Khorami, A. F. (1991). A study of negative information, the impact of time pressure and the order the negative information is placed in a message on consumer attitudes, behavior and decision-making on both student and nonstudent subjects. (Unpublishe doctoral dissertation). Minneapolis, MN: Walden University.

Langer, D. (2019). A summit on the true future of luxury. Jing Daily. Retrieved from https://bit.ly/2knzdCc

Lekvall, P., \& Wahlbin, C. (2001). Information for marketing decisions (4th ed.). Gothenburg, Sweden: IHM.

Magnusson, P., Krishnan, V., Westjohn, S. A., \& Zdravkovic, S. (2014). The spillover effects of prototype brand transgressions on country image and related brands. Journal of International Marketing, 22(1), 21-38. doi: https://doi.org/10.1509/jim.13.0068

Oppenheim, A. N. (1992). Questionnaire design, interviewing and attitude measurement (new ed.) (Vol. 24). New York, NY: Pinter Publishers.

Park, C. W., MacInnis, D. J., Priester, J., Eisingerich, A. B., \& Iacobucci, D. (2010). Brand attachment and brand attitude strength: Conceptual and empirical differentiation of two critical brand equity drivers. Journal of Marketing, 74(6), 1-17. doi:https://doi.org/10.1509/jmkg.74.6.1

Raju, S., Unnava, H. R., \& Montgomery, N. V. (2009). The moderating effect of brand commitment on the evaluation of competitive brands. Journal of Advertising, 38(2), 21-36. doi:https://doi.org/10.2753/JOA0091-3367380202

Ramly, S. M., \& Omar, N. A. (2016). The relative contribution of loyalty programs and store attributes to store engagement and equity. Journal of Administrative and Business Studies, 1(1), 42-52.

Schiffman, L. G., \& Kanuk, L. L. (2000). Consumer behavior (7th ed.). New York, NY: Prentice Hall. 
Sherrell, D., Reidenbach, R. E., Moore, E., Wagle, J., \& Spratlin, T. (1985). Exploring consumer response to negative publicity. Public Relations Review, 11(1), 13-28. doi:https://doi.org/10.1016/S0363-8111(85)80057-6

Sierra, J. J., \& Hyman, M. R. (2011). Outlet mall shoppers' intentions to purchase apparel: A dual-process perspective. Journal of Retailing and Consumer Services, 18(4), 341-347. doi:https://doi.org/10.1016/j.jretconser.2011.03 .002

Solomon, M. R. (2008). Consumer behavior buying, having and being (8th ed.). Upper Saddle River, NJ: Pearson Prentice Hall.

Tariq, M. I., Nawaz, M. R., Nawaz, M. M., \& Butt, H. A. (2013). Customer perceptions about branding and purchase intention: A study of FMCG in an emerging market. Journal of Basic and Applied Scientific Research, 3(2), 340-347.

Ullrich, S., \& Brunner, C. B. (2015). Negative online consumer reviews: Effects of different responses. Journal of Product \& Brand Management, 24(1), 66-77. doi:https://doi.org/10.1108/JPBM-05-2014-0611

Wichailert, K., \& Yousapornpaiboon, K. (2017). Brand equity affects brand loyalty of the bottled mineral drinking water in thailand. Journal of Administrative and Business Studies, 3(4), 180-191. doi:https://doi.org/10.20474/ jabs-3.4.3

$\mathrm{Wu}, \mathrm{J}$. (2011). The effects of brand crisis on brand evaluation and consumer's willingness of brand relationship rebuilding: The moderating effect of self-image congruence. In Proceedings of International Conference on Information Systems for Crisis Response and Management (ISCRAM) (p. 303-307). Harbin, China.

Yang, Y., \& Liu, N. (2018, November). Dolce \& Gabbana goods pulled from Chinese ecommerce sites. British Times. Retrieved from https://on.ft.com/21IVbzv

Yu, M., Liu, F., Lee, J., \& Soutar, G. (2018). The influence of negative publicity on brand equity: Attribution, image, attitude and purchase intention. Journal of Product \& Brand Management, 27(4), 440-451. doi:https://doi.org/ 10.1108/JPBM-01-2017-1396 